\title{
The Embodiment and Development of Feminism in English and
}

\section{American Literature}

\author{
Ji Fan \\ Liaoning Jianzhu Vocational College, Liaoyang, Liaoning,China 111000 \\ Jifanhy@163.com
}

Keywords: English and American Literature; Feminism; Sexism

Abstract.

The more complete expression and embodiment of feminism in English and American literature was proposed by the French novelist Alexandre Dumas fils, which originated from the eighteenth century enlightenment era thinker. In the case of A Vindication of the Rights of Woman, Mary Wollstonecraft said that women should enjoy equal treatment with men in terms of education, employment and politics. Feminism in the nineteenth century gradually transformed into an organized social movement, Qasim Amin in the Tahriral-Mar'a worked to promote women's education and criticized the social customs at that time. The development of feminism in English and American literature can be divided into three stages, forming a unique feminism theory, mainly embodied in the socialist feminism, liberal feminism and radical feminism. In addition to criticism, those works also focused on the analysis of gender inequality, understood the nature of inequality, and promoted the change of power relations and sexual consciousness, to fulfill the goal of women's liberation.

\section{Introduction}

Feminism refers to the social theory and political movement that were created and initiated for the end of sexism, sexual exploitation, sexual discrimination and sexual oppression, and promoting class equality. The feminism conceptual basis is that the current society is based on a male-centered patriarchal system. Feminist political action challenges topics such as reproductive rights, abortion rights, educational rights, domestic violence, maternity leave, salary equality, voting rights, representation, sexual harassment, gender discrimination and sexual violence. English and American literature on feminism has a complete process of expression, and feminism is more in the English and American literature. In the works of English and American literature, female characters try to win the dignity, equality and freedom of women in terms of gender power, social power, political power and so on, through their critique of abnormal social relations with their encounters, circumstances, fate and so on [1].

\section{The Division of Western Feminism in English and American Literature}

The themes of feminist inquiry include discrimination, stereotype, materialization (especially about materialization), physical, oppression and patriarchy. The feminist movement is a social movement that transcends class and racial boundaries, and the feminist movements beneath each culture have their own uniqueness and will raise questions about women in society. Feminism refers to the social thought that women demand equal rights. Which was first proposed by the French novelist Alexandre Dumas fils in 1872. "Jane Eyre "," Heroine Character "," Pride and Prejudice "," 
Austin's Love and Marriage "," The Tragic Fate of The Heroine "and other literary works have a profound elaboration of feminism. According to the embodiment and development of feminism in English and American literature, Western feminism can be divided into three stages [2]:

The first generation of feminism (the second half of the nineteenth century to the beginning of the twentieth century) - the stage of origin. Western feminism originated after the bourgeois revolution and the Enlightenment. It appeared in the second half of the nineteenth century, and was synchronized with the European industrial revolution.

This stage of the characteristics of feminism is: the goal is clear; women and men have the same economic and political power; action and practice based, and focusing on promoting legislation. This stage laid the goal of the struggle of the feminist movement, also formed the tone that a feminist movement is a social practice movement. In the final analysis, education, employment and political rights is the most sought for women to pursue equal social role status, and irrational labor market is the biggest obstacle to the feminist movement. It can be said that seeing the disadvantaged status of women in the labor market as an important source of inequality between men and women social status took shape in this stage. Although the theory of feminist ideology has evolved, and the environmental background of the labor market is constantly changing, this concept is still deep in the feminist [3].

The second generation of feminism (from the early twentieth century to the 1960s) - modern feminism. This stage is the most important stage of feminism in the West. Feminists have found that women's unequal status in social life has not been fundamentally improved, despite the women's efforts of striving for equality in the areas of political and economy had achieved tangible results. For example, women who received the right to vote were still subordinate to politics; under the circumstances of equal pay for equal work, equal employment was basically guaranteed, the problem of professional isolation and poor career development prospects still highlighted. This contradictory situation prompted the feminists to think deeply, forming a unique feminist theory, there are three factions:

Socialist feminism: The representative of this faction is the British Juliette Mitchell, her most famous "raised the feminist question, given the Marxist answer" clearly showed the banner of Marxism. Socialism feminism mainly demanded equality between women and men in terms of economic and class struggle, and they attached importance to women's economic status and material life. Although there are different interpretations, Engels' "family, private ownership and the origin of the state" is an important theoretical source of socialist feminism. No exchange of value, unpaid family labor was regarded as class oppression, and actively engaged in social production labor [4]. On the issue of emphasis on the field of production economy, socialist feminism is the direct successor of the first generation of feminism.

Liberal feminism: The representative of this faction is the nineteenth century British Mill, and contemporary American Friedan. Mill is the British nineteenth century liberal master, his masterpiece "women's yield" focused on his views on the rights and interests of women. Mill pointed out that the law of inequality makes marriage system marriage relationship is like the relationship between the owner and the slave. In modern society, people have the freedom to migrate, choose occupation, and improve the chances of life. However the married women do not have the same freedom as those modern men. Friedan inherited the basic idea of liberalism since the eighteenth century, while more emphasis on women's participation in the public domain. She encouraged women to give up the image of housewives as self-identity, strike balance between career and family, rather than giving up family life. Liberal feminists argue that family restraint is a powerful source of interference and must rely on national legislation to intervene and form an 
intervention mechanism. Therefore, the liberal feminist movement inherited the mantle of the liberal movement, strived for legislative protection as the main demands, and actively safeguarded the political rights of women.

Radical feminism: This faction was born the latest, being active in 1960s to 1970s. Strictly speaking, this faction is not a unified ideological faction, but concentrated performance of extreme concept of the first two factions of thought. It interpreted the exploitation of socialist feminist private production as "sexual exploitation" and interpreted the family bond of liberal feminism as "sexual bondage", and they completely confronted women and men. For the traditional areas of the feminist movement - social politics and the economy, they held a contemptuous attitude, they interpreted the women's liberation movement as "sexual liberation", required a fundamental digestion of the traditional family model. Their radical assertion and "liberation movement" had aroused great controversy in society.

The third generation feminism - postmodern feminism. In the face of the "sexual liberation movement" caused serious social consequences such as the strong question of conservatism on the women's liberation movement the divorce rate increased significantly and the spread of AIDS, etc., feminists began to rethink. Especially in the elimination of male and female binary opposition, the "gentle feminism" and "green feminism" were formed. On the one hand, they affirmed the feminist movement to protect women's social rights and interests; on the other hand, they questioned those feminists trying to subvert the traditional family model. Postmodern feminism is still in the stage of growth, divided into the two main factions of the theory and constitution. Although their theoretical starting points are different, all achieve the goal of women's liberation based on the acknowledgement of the traditional family model [5].

\section{The Embodiment of Literary works}

From the point of view of modern philosophy and social movement, feminism is usually originated in the eighteenth century Enlightenment era thinkers. Such as A Vindication of the Rights of Woman, written by Mary Wollstonecraf, is one of the few books that could be called feminist before the nineteenth century. She believes that women are noble, social elite, spoiled, fragile and having the risk of knowledge and moral laziness. She believes that men and women are responsible for such a situation, and that a woman having more power than a man is a matter of course. But this is not to say that there were no other books on gender equality earlier. For example, Mystic philosopher Heinrich Cornelius Agrippa wrote A Distinguished Speech About Women in 1529.

A very important support factor for modern feminism is the book "The Sex and Temperament of the Three Primitive Tribes" published by anthropologist Margaret Mead (1935). In the report of this book, women of the Tchambuli tribe have a dominant position, but have not caused any problems. Women's special journals, such as the special issue of scientific issues, began to flourish during this period.

In 1848, the first women's congress was held in SenecaFalls, NewYork, United States. Emmeline Pank hurst is one of the founders of the women's political power movement. She set up The Women's Social and Political Union (WSPU), aiming at exposing institutionalized gender discrimination in British society. It is noteworthy that the nineteenth century feminists include Emma Goldman, Elizabeth Cady Stanton and Margaret Sanger. The feminist in the Arab world is the Egyptian jurist Qasim Amin. Qasim Amin was the father of the Arab feminist movement, and in 1899 he wrote a pioneering book, Tahriral-Mar'a. Qasim Amin criticized social practices at the time, such as polygamy, veil, or quarantine of women, condemning these practices as being incompatible with the true spirit of Islam. His works have had a tremendous impact on the political movement of 
women in Islam, and are still cited today. What is less known, however, is that women who have criticized their society from the feminist point of view before Qasim Amin. Feminist began in the Enlightenment era thinkers, such as Mary Wortley Montagu and Marquisde Condorcet, who promoted female education. There are also many liberal thinkers, such as Jeremy Bentham, who have equal power in all respects.

\section{The Development Faction of Feminism in English and American Literature}

In the English and American literature, there are many factions of feminism. Because of the historical background, the legal status of women in some countries, and other factors, feminism has varies kinds of lines in order to achieve different purposes.

Free and unchained feminism. The goal of free and unchained feminism is the establishment of social justice, the equality between the sexual opportunities, the implementation of family autonomy and the access to women's survival and development of freedom. And to do this, it is needed to eventually being out of the sex, beyond the gender differences and through the humanitarian justice to access to new liberation. Political science theorist Susan Okin in the "fair, sexual and family" pointed out that in the United States advertised in the free and equal kingdom, in fact, there is still inequality between men and women. She wrote, "In fact, inequality between sexes still exists in our society." This kind of feminism's efforts for social justice and gender equality to fight, is well known in the world. At the same time, it is also actively advocating the fight against social and family tyranny and resistance.

Radical feminism. Radical feminism sees that social inequality created inequality between the sex class and the gender class. It hoped to achieve a "gender dialogue" through social differences and antagonism. To achieve this step, all kinds of exposition, struggle and protest to patriarchy, the resulting oppression of women and the separation of power are also needed. The famous American radical feminist Andrew Dworkin proposed that "obscene publications violate the citizenship of women" and advocated allowing individual women to sue for losses caused by obscene publications and to establish this new offense. She pointed out that the original intention of the ancient Greek root "porne" is the most down prostitutes, and the female image in obscene publications is the same as the female prostitutes. She emphasized that obscene publications are a form of violence that awakens the instincts of men and points them to women. Dworkin is more aware of the tragic experience of women and more to stimulate her bravery, opened the privacy of male politics. Catherine McKinnon's "Pornographic Description, Civil Rights and Speech," revealed that pornography described the substance as a mandatory means of gender discrimination against women and the conquest of violence against women. As she pointed out, "men are subject to male supremacy, and if anything happens, it will happen because of what feminists say is a form of power, and women are powerless A form".

Cultural feminism. Cultural feminism emphasizes equality of sex, as well as caring for people, and that care was unique and individual to each individual. According to this view, women pay more attention to creating and maintaining a warm, intimate and caring relationship with others, while men are more interested in affirming their own, controlling their own and others' destiny. Cultural feminism focused on performing women 's care and moral care with love. Nel Noddings pointed out that women usually define themselves as incarnations of both morality and caring morality. When we move from natural concern to moral care, we will see that this definition of the model has a very profound psychological structure on the basis. There are two kinds of coercion, which must distinguish between active care and being cared.

Socialist feminism. Socialism feminism focuses on "women: status, class or oppressed gender" and 
other issues. The main content of this Marxist feminist theory is to explore the root cause of the oppression of women from the perspective of the history of human society development. According to the Marxist classical theorist's argument, its roots generally have three aspects. The first one is the emergence of private ownership of production. As the emergence of private ownership, men both become the owner of the land, has become a female owner, which is "the history of women with a historic failure." Second, the monogamous family in history makes women subordinate. Engels, based on the results provided by the anthropologist Moore's "Ancient Society," points out that the individual marriage, that is, monogamy in the history of the transition from couples, is only for women, not for men. Men can arbitrarily satisfied slaves as concubine, and his wife will have to adhere to chastity, her husband in the family in the dominant position, his wife in addition to birth, but the maidservant's leader. It can be seen that "the modern individual family is based on the family slavery of open or hidden women". Third, one of the root causes of their oppression is that women are weak. With the emergence of private ownership, women are excluded from social production, but only in the family engaged in private labor. At this time the female housework has lost the nature of the past, become a servant of the family. In addition, there is also a very important content of Marxist theory is to attach great importance to the oppressed women in the creation of history, to promote the great changes in the important role of society. As Marx emphasized, "social progress can be measured precisely by the social status of women." Lenin also said, "From the experience of all liberation movements, the success of the revolution depends on the degree to which women participate in the movement.

Postmodern feminism. The struggle of postmodern feminism and post-feminism is to create female culture with female discourse, to obtain and master the female's right to speak, and to become the subject of discourse in the practice of women's discourse. Feminists use the theory of deconstruction to enrich and develop feminist theory. In the time of "women's time", Christieva provided a distinction between women in time and the division of feminist development in order to explain the changes in the feminist concept and the feminist genre difference. The most acute criticism of postmodern feminism and postmodernism points to its non-political or post-political tendencies, and the patriarchal relations of the industrialized base are strengthened in many ways. The employment contract has made many provisions for restricting women to low wages, less income and fewer opportunities for development, which is an example of male supremacy or a male supremacy ideology.

In the "Feminism in the Protection of the Ecological Environment: Power and Commitment", the author wished to change the misconceptions and bad habits of nature and of women for thousands of years, to eliminate words and deeds that ignore the power of nature and women, and abolish naturalism and gender discriminatory. In the book "From the heroic ethics to the comprehensive ethics: the ecological and environmental feminist challenge", Kiel compared what she said "heroic ethics" and "comprehensive ethics", that the former was male, man temperament or militarist, the latter was feminine or feminist.

\section{Conclusions}

The embodiment and development of feminism in English and American literature is not a single thought, and its internal view on many issues is not the same, either. And feminism also believes that there is no single truth in the world, thus there is no definition of "true feminism", feminism is only "a concept, each expression". The feminists in English and American literature have the following commonalities: believing that the real world is a world of gender inequality; believing that gender inequality should change; attaching importance to and understanding women's 
experience.

\section{Reference:}

[1] DONG Jinping, Marx's feminist frontier and its internal logic [J].Journal of Nanjing University(Philosophy,Humanities and Social Sciences)

[2] 106-110. ZHOU Liping. On the eco feminist consciousness in the black dog[J]. Journal of Jixi University, ,2017,17(3): 106-110.

[3] OLESYA LOBANOVA,SHAHID S. HAMID,ARUN J. PRAKASH. Shot Sales Ban and Stock Market Liquidity: The Comparison of NYSE and NASDAQ-Listed Stocks[J]. International Journal of Finance,2011,23 (2): 6750-6763.

[4] TAGUCHI,H.,SAHOO,P., NATARAJ,G. Capital Flows and Asset Prices: Empirical Evidence from Emerging and Developing Economies[J]. International Economics,2015,141 (5): 1-14

[5] DICK CD,MENKHOFF L. Exchange Rate Expectations of Chartists and Fundamentalists[J]. Journal of Economic Dynamics and Control,2013,37 (7): 1362-83. 